\title{
RESEARCH
}

Open Access

\section{Evaluation of almond young trees growth and nutritional status under different slow- release compound fertilizer types and doses at Nubaria region}

\author{
E. K. Nabila, M. S. Abourayya, Thanaa Sh. M. Mahmoud*'D, R. A. Eisa, Amal M. Rakha and O. A. Amin
}

\begin{abstract}
Background: Slow-release fertilizers (SRF) are quite numerous, and diverse group of materials are involved in the improvement of the effectiveness of fertilization, mitigation of the negative impact of fertilizers on the environment, and the reduction of labor and energy consumption connected with the application of conventional fertilizers. The objective of the experiment was to measure vegetative growth parameters and nutritional status of Nonpareil almond young trees under two types of slow-release compound fertilizers: Matador at 30, 60, and $120 \mathrm{~kg} /$ Feddan and Nitrophoska at $(25,50$, and $100 \mathrm{~kg} /$ Feddan. The experiment was conducted in the Experimental Research Station of National Research Centre at Nubaria, El Behera governorate, Egypt, during successive growing seasons 2018 and 2019.
\end{abstract}

Results: The results indicated that increasing doses of slow-release fertilizer significantly improved vegetative growth of trees. The highest dose of Nitrophoska had significantly higher stem length, diameter, numbers of branches and leaves/trees, leaf area, leaf chlorophyll content, leaf fresh and dry weight while the highest significant of specific leaf dry weight was obtained by applying the highest dose of Matador compared with control trees that received the fast-release fertilizer NPK 19:19:19 at $200 \mathrm{~kg} /$ Feddan. Leaf mineral contents of some macro (N, P, K and $\mathrm{Mg}$ ) and micro elements (Fe, Mn, Zn, and $\mathrm{Cu}$ ) were significantly increased as a result of application with slowrelease fertilizers. Nitrophoska at $100 \mathrm{~kg} /$ Feddan gave the highest values of nitrogen, potassium, magnesium, and iron while Matador at $120 \mathrm{~kg} / F e d d a n$ gave the highest value of manganese. Matador at all doses resulted in a significant increment in phosphorus concentration in leaves in both seasons. Nitrophoska at $100 \mathrm{~kg} / F e d d a n$ and Matador at $120 \mathrm{~kg} /$ Feddan recorded the highest values of zinc and copper without significant differences between them.

Conclusions: It could be concluded that application with slow-release fertilizers resulted in a positive and significant influence on most investigated vegetative growth measurements and leaf mineral contents of Nonpareil almond trees, since the application with Nitrophoska at $100 \mathrm{~kg} / F e d d a n$ was the most effective treatment for increasing growth measurements and improving leaf nutritional status of Nonpareil almond trees grown under Nubaria condition.

Keywords: Slow release, Almond, Young trees, Nitrophoska, Matador, Vegetative growth, Leaf mineral contents

* Correspondence: thanaa_3000@yahoo.com

Department of Horticultural Crops Technology, National Research Centre,

Dokki, Giza, Egypt 


\section{Background}

Nutrient losses in fertilization have often become a problem that causes the low efficiency and environmental pollution issues. About $40-70 \%$ nitrogen, $80-$ 90\% phosphorus, and $50-70 \%$ potassium of the applied fertilizers are lost to the environment and cannot be absorbed by plants (Wu and Liu, 2008). The losses of these nutrients from the soil can be caused by leaching (washing off) by the rainfall, irrigation water, and runoff. Besides causing economic losses, nutrient losses by leaching especially for $\mathrm{N}$ and $\mathrm{P}$ may lead to environmental problems such as pollution, groundwater contamination, and eutrophication in the aquatic environment (Himmah et al., 2018). One way to minimize those environmental hazards, while improving the efficiency of nutrient use, is by using slow-release or controlled-release fertilizers (Shaviv and Mikkelsen, 1993). Slow-release fertilizers are made of materials complex structure and little solubility in water such as the urea-kaolin products. Various synthetic organic products, matrix-based formulations, with the nutrients dispersed in the polymeric or inorganic matrices and polyphosphate-based micronutrient fertilizers so, release their nutrient contents gradually and coincide with the nutrient requirement of plant (AlShamaileh et al., 2018). Thereby, they can minimize the pollution of soil and water associated with fertilizer over dosage and leaching. Slow-release fertilizers have good properties, are cost-saving and environment friendly, and thus can efficiently improve the utilization efficiency of fertilizers in agricultural production (Pang et al., 2018); they found that release amounts of N, P, and $\mathrm{K}$ after 5 days were $95.39,95.28$, and $96.75 \%$ in water, and 83.35 , 96.62, and $90.75 \%$ in soil, respectively. However, little is known about the effects of slow-release compound fertilizers especially under new reclaimed lands' conditions. Therefore, the objective of this work was to explore the efficiency of two types of slow-release compound fertilizers on growth and nutritional status of Nonpareil almond young trees grown under Nubaria conditions.

\section{Materials and methods}

The experiment was conducted during the two successive seasons of 2018 and 2019 on 3-year-old Nonpareil almond young trees (Prunus amygdalus B.) budded on bitter almond rootstock uniform in vigor, with planting space $5 \times 5 \mathrm{~m}$ (168 trees/Feddan) grown in sandy soil under drip irrigation system in the Experimental Research Station of National Research Centre at Nubaria, El Behera governorate, Egypt. The chemical and physical properties of the soil are presented in Table 1. The experiment includes the following treatments:
Table 1 Physical and chemical properties of the experimental soil

\begin{tabular}{lllllllll}
\hline $\begin{array}{l}\text { Sand } \\
(\%)\end{array}$ & $\begin{array}{l}\text { Silt } \\
(\%)\end{array}$ & $\begin{array}{l}\text { Clay } \\
(\%)\end{array}$ & Texture & $\begin{array}{l}\mathrm{OM} \\
(\%)\end{array}$ & $\mathrm{EC} \mathrm{dSm}{ }^{1}$ & $\mathrm{pH}$ & $\mathrm{HCO}^{-3}$ & $\mathrm{CO}^{-3}$ \\
\hline 81.71 & 9.01 & 7.89 & Sandy & 2.84 & 0.54 & 7.88 & 1.7 & ----- \\
$\mathrm{Cl}^{-}$ & $\mathrm{SO}_{4}^{-2}$ & $\mathrm{Ca}^{+}$ & $\mathrm{Mg}^{+2}$ & $\mathrm{Na}^{+}$ & $\mathrm{K}^{+}$ & $\mathrm{N} \%$ & $\mathrm{P} \%$ & $\mathrm{~K} \%$ \\
3.2 & 0.41 & 2.3 & 2.25 & 0.3 & 0.45 & 0.99 & 0.42 & 0.54 \\
\hline
\end{tabular}

A. Fertilizer type:

1. Matador@ $(20 \%$ N, $20 \%$ P, 5 \% K, 5 \% S, $1 \%$ Zn and it contains trace amount of free calcium, magnesium, iron, copper, and manganese.

2. Nitrophoska $\odot(25 \% \mathrm{~N}, 10 \% \mathrm{P}, 17.15 \% \mathrm{~K}, 4 \% \mathrm{~S}$, $1.55 \% \mathrm{Mg}, 0.01 \% \mathrm{~B}, 0.019 \% \mathrm{Cu}, 0.05 \% \mathrm{Fe}, 0.05 \%$ $\mathrm{Mn}, 0.001 \% \mathrm{Mo}$ and $0.019 \% \mathrm{Zn}$ ).

\section{B. Fertilizer dose:}

1. Matador@ at $30,60,120 \mathrm{~kg} /$ Feddan.

2. Nitrofosca@ at $25,50,100 \mathrm{~kg} /$ Feddan.

Using different doses of the two slow-release compound fertilizers due to difference between element concentration content in them, consequently the used doses of the two fertilizers are equal. The two slow-release compound fertilizers at the pre-mentioned amounts were applied once at the start of growth season in a circular hole around tree $10 \mathrm{~cm}$ apart from the tree stem and covered with soil. Control trees received the normal recommended fast-release mineral fertilizer NPK 19:19: 19 at $200 \mathrm{~kg} /$ Feddan, and it was added on bimonthly doses from beginning of growing season until September with irrigation water. Other horticultural practices were carried out as usual.

The following parameters were recorded for both seasons:

1. Vegetative growth measurements At mid-August of the two seasons, stem length of tree $(\mathrm{cm})$ and diameter of tree $(\mathrm{mm})$, numbers of branches/tree, numbers of leaves/tree, leaf fresh weight $(\mathrm{g})$, and leaf dry weight $(\mathrm{g})$ were determined. Leaf area $\left(\mathrm{cm}^{2}\right)$ was measured by using $\mathrm{Cl}-202$ portable laser leaf area meter. Specific leaf dry weight SLDW $\left(\mathrm{mg} / \mathrm{cm}^{2}\right)$ was determined by the following equation: 
Specific leaf dry weight $=\frac{\text { leaf dry weight }(\mathrm{g})}{\text { Leaf area }(\mathrm{cm} 2)} \times 1000$

Leaf chlorophyll content was measured in the field by using chlorophyll meter model SPAD- 502.

2. Leaf mineral contents

Leaves samples were picked from the middle portion of the current season growth to each treatment washed and dried at $70^{\circ} \mathrm{C}$ till a constant weight for determination of the following nutrient elements (percentage as dry weight) $\mathrm{N}, \mathrm{P}, \mathrm{K}, \mathrm{Mg}$, $\mathrm{Zn}, \mathrm{Fe}, \mathrm{Mn}$, and $\mathrm{Cu}$ according to AOAC (1985).

\section{Statistical analysis}

The design of the experiment was completely randomized block design with three replicates each consisted of five trees. All data were subjected to analysis of variance (ANOVA) as described by Mstat-C (1989), and the least significant differences (L.S.D) at 5\% were used to compare between treatments means.

\section{Results}

\section{Vegetative growth}

It is clear from Tables 2 and 3 that application of two types of slow-release compound fertilizers, Matador and Nitrophoska, resulted in positive effect and significantly improved vegetative growth of Nonpareil almond young trees during 2018 and 2019 seasons.

The promotion on vegetative growth; stem length, diameter, numbers of branches and leaves/tree; and leaf area were associated with increasing the doses of Matador and Nitrophoska compared with application of fast-release fertilizer NPK 19:19:19. The maximum stem length $(98.15$ and $100.6 \mathrm{~cm})$, diameter (13.05 and $14.56 \mathrm{~mm}$ ), numbers of branches (38 and 40.22), numbers of leaves (456 and 460), and leaf area $\left(3.35\right.$ and $\left.3.62 \mathrm{~cm}^{2}\right)$ were detected on the trees fertilized with Nitrophoska at $100 \mathrm{~kg} /$ Feddan during both seasons of the study respectively. Meanwhile, the minimum stem length (57 and $59.56 \mathrm{~cm}$ ), diameters $(8$ and $9 \mathrm{~mm})$, numbers of branches $(9$ and 10.09), numbers of leaves (162 and 165), and leaf area $\left(2.59\right.$ and $\left.2.86 \mathrm{~cm}^{2}\right)$ were detected on the trees fertilized with NPK 19:19:19 during both seasons respectively.

Concerning leaf fresh and dry weight, the application of Nitrophoska at $100 \mathrm{~kg} /$ Feddan recorded the highest significant values (4.54 and 6.66, and 2.41 and $3.11 \mathrm{~g}$ ) followed by application of Matador at $120 \mathrm{~kg} /$ Feddan (4.12 and 6.38, and 2.30 and $2.85 \mathrm{~g}$ ) during both seasons, respectively, while fast-release fertilizer NPK 19:19:19 recorded the lowest values of leaf fresh and dry weight ( 2.80 and 3.68 , and 1.00 and $1.20 \mathrm{~g}$ ) during both seasons respectively and was not significant with application of Matador at $30 \mathrm{~kg} /$ Feddan (Table 3).

Regarding specific leaf dry weight (Table 3), in 2018 application of Matador at $120 \mathrm{~kg} /$ Feddan gave the highest significant values $\left(756.8 \mathrm{mg} / \mathrm{cm}^{2}\right)$ followed by application of Nitrophoska at $100 \mathrm{~kg} /$ Feddan $\left(719.3 \mathrm{mg} / \mathrm{cm}^{2}\right)$, while the lowest values $\left(369 \mathrm{mg} / \mathrm{cm}^{2}\right)$ were recorded on trees fertilized with Matador at $30 \mathrm{~kg} /$ Feddan and were not significant with trees fertilized by Nitrophoska at 50 $\mathrm{kg} /$ Feddan and NPK 19:19:19. In 2019, application of Matador at $120 \mathrm{~kg} /$ Feddan gave the highest values (861 $\mathrm{mg} / \mathrm{cm}^{2}$ ) and was not significant with application of Nitrophoska at $100 \mathrm{~kg} /$ Feddan, whereas the lowest values of specific leaf dry weight $\left(413 \mathrm{mg} / \mathrm{cm}^{2}\right)$ were recorded on trees fertilized with Matador at $30 \mathrm{~kg} /$ Feddan and were not significant with trees fertilized by fast-release fertilizer NPK 19:19:19.

As for leaf chlorophyll content, the application of Nitrophoska at $100 \mathrm{~kg} /$ Feddan recorded the highest significant values (45.33 and 45.89) followed by application of Matador at $120 \mathrm{~kg} /$ Feddan (44.08 and 45.75) during both seasons, respectively, while application of Matador at $30 \mathrm{~kg} /$ Feddan recorded the lowest significant values

Table 2 Effect of different slow-release compound fertilizer types and doses on stem length, diameter, numbers of branches and leaves/tree of Nonpareil almond young trees

\begin{tabular}{|c|c|c|c|c|c|c|c|c|}
\hline \multirow[t]{2}{*}{ Treatments } & \multicolumn{2}{|c|}{$\begin{array}{l}\text { Stem length } \\
(\mathrm{cm})\end{array}$} & \multicolumn{2}{|c|}{$\begin{array}{l}\text { Stem diameter } \\
(\mathrm{mm})\end{array}$} & \multicolumn{2}{|c|}{ No. of branches/tree } & \multicolumn{2}{|c|}{ No. of leaves/tree } \\
\hline & 2018 & 2019 & 2018 & 2019 & 2018 & 2019 & 2018 & 2019 \\
\hline Matador@ at $30 \mathrm{~kg} /$ Feddan & $68.79 e$ & $70.56 f$ & $8.50 \mathrm{~cd}$ & $9.00 \mathrm{e}$ & $14.00 \mathrm{e}$ & $16.11 f$ & $209 f$ & $212 f$ \\
\hline Matador@ at $60 \mathrm{~kg} /$ Feddan & $80.50 d$ & $83.06 \mathrm{e}$ & $8.24 d$ & $10.06 d$ & $16.00 d$ & $18.43 e$ & $212 e$ & $215 e$ \\
\hline Matador@ at $120 \mathrm{~kg} /$ Feddan & $90.00 \mathrm{c}$ & $92.42 d$ & $9.10 c$ & $10.13 d$ & $21.00 \mathrm{c}$ & $23.05 d$ & $221 d$ & $224 d$ \\
\hline Nitrophoska@ at 25 kg/Feddan & $90.11 \mathrm{c}$ & $96.23 c$ & $10.00 b$ & $11.00 \mathrm{c}$ & $24.00 \mathrm{~b}$ & $26.18 c$ & $301 c$ & $305 c$ \\
\hline Nitrophoska@ at 50 kg/Feddan & $96.00 \mathrm{~b}$ & $98.56 b$ & $10.11 b$ & $11.88 \mathrm{~b}$ & $37.00 \mathrm{a}$ & $39.00 \mathrm{~b}$ & $378 b$ & $382 b$ \\
\hline Nitrophoska@ at $100 \mathrm{~kg} /$ Feddan & $98.15 a$ & 100.6a & $13.05 a$ & $14.56 a$ & $38.00 a$ & $40.22 \mathrm{a}$ & $456 a$ & $460 a$ \\
\hline Control & $57.00 f$ & $59.56 \mathrm{~g}$ & $8.00 d$ & $9.00 \mathrm{e}$ & $9.00 f$ & $10.09 \mathrm{~g}$ & $162 \mathrm{~g}$ & $165 \mathrm{~g}$ \\
\hline
\end{tabular}

Means in each column with similar letters are not significantly different 
Table 3 Effect of different slow-release compound fertilizer types and doses on leaf area, leaf fresh weight, leaf dry weight, specific leaf dry weight and leaf chlorophyll content of Nonpareil almond young trees

\begin{tabular}{|c|c|c|c|c|c|c|c|c|c|c|}
\hline \multirow[t]{2}{*}{ Treatments } & \multicolumn{2}{|c|}{ Leaf area $\left(\mathrm{cm}^{2}\right)$} & \multicolumn{2}{|c|}{$\begin{array}{l}\text { Leaf fresh weight } \\
\text { (g) }\end{array}$} & \multicolumn{2}{|c|}{$\begin{array}{l}\text { Leaf dry weight } \\
\text { (g) }\end{array}$} & \multicolumn{2}{|c|}{$\begin{array}{l}\text { Specific leaf dry weight } \\
\left(\mathrm{mg} / \mathrm{cm}^{2}\right)\end{array}$} & \multicolumn{2}{|c|}{$\begin{array}{l}\text { Leaf chlorophyll } \\
\text { content }\end{array}$} \\
\hline & 2018 & 2019 & 2018 & 2019 & 2018 & 2019 & 2018 & 2019 & 2018 & 2019 \\
\hline Matador@ at $30 \mathrm{~kg} /$ Feddan & $2.71 f$ & $2.98 \mathrm{e}$ & $2.81 \mathrm{f}$ & $3.72 f$ & $1.00 f$ & $1.23 f$ & $369 e$ & $413 e$ & $30.25 \mathrm{~g}$ & $31.28 \mathrm{~g}$ \\
\hline Matador@ at $60 \mathrm{~kg} /$ Feddan & $2.74 \mathrm{e}$ & $3.01 \mathrm{C}$ & $3.01 \mathrm{e}$ & $4.18 \mathrm{e}$ & $1.33 d$ & $1.90 \mathrm{~d}$ & $485.3 d$ & $631.3 c$ & $40.52 d$ & $42.64 d$ \\
\hline Matador@ at $120 \mathrm{~kg} /$ Feddan & $3.04 d$ & $3.31 b$ & $4.12 b$ & $6.38 b$ & $2.30 b$ & $2.85 b$ & $756.8 \mathrm{a}$ & $861 a$ & $44.08 \mathrm{~b}$ & $45.75 b$ \\
\hline Nitrophoska@ at 25 kg/Feddan & $3.05 c$ & $3.32 b$ & $3.16 \mathrm{~d}$ & $4.47 d$ & $1.62 \mathrm{C}$ & $2.40 c$ & $531 c$ & $723 b$ & $40.11 \mathrm{e}$ & $42.59 \mathrm{e}$ \\
\hline Nitrophoska@ at $50 \mathrm{~kg} /$ Feddan & $3.07 b$ & $3.34 b$ & $3.44 \mathrm{c}$ & $4.92 \mathrm{c}$ & $1.20 \mathrm{e}$ & $1.65 \mathrm{e}$ & $391 e$ & $494.3 d$ & $42.36 c$ & $43.02 \mathrm{C}$ \\
\hline Nitrophoska@ at 100 kg/Feddan & $3.35 \mathrm{a}$ & $3.62 \mathrm{a}$ & $4.54 a$ & $6.66 a$ & $2.41 \mathrm{a}$ & $3.11 \mathrm{a}$ & $719.3 b$ & $859 a$ & 45.33a & $45.89 a$ \\
\hline Control & $2.59 \mathrm{~g}$ & $2.86 f$ & $2.80 f$ & $3.68 \mathrm{f}$ & $1.00 f$ & $1.20 f$ & $386 e$ & $419.8 e$ & $37.27 f$ & $41.41 \mathrm{f}$ \\
\hline
\end{tabular}

Means in each column with similar letters are not significantly different

(30.25 and 31.28) during both seasons respectively (Table 3).

\section{Leaf mineral content}

It is evident from the results presented in Tables 4 and 5 the effect of slow-release compound fertilizers, Matador and Nitrophoska, on macro and micro element percentages in Nonpareil leaves in 2018 and 2019 seasons.

Increasing doses of slow-release Nitrophoska fertilizer resulted in an increment of nitrogen concentration in leaves. The highest dose of Nitrophoska gave significantly higher nitrogen (1.71 and $1.75 \%)$ than control trees which received NPK 19:19:19 (1.22 and 1.41\%) during 2018 and 2019 seasons respectively (Table 4).

Table 4 illustrated that the application of Matador 120 $\mathrm{kg} /$ Feddan stimulated the highest phosphorus concentration in leaves followed by Matador at $60 \mathrm{~kg} /$ Feddan then Matador at $30 \mathrm{~kg} /$ Feddan $(1.85,1.82$, and $1.76 \%)$ in the first season respectively and (1.90, 1.88 and $1.82 \%)$ in the second season respectively, while the lowest phosphorus concentration in leaves was observed on the trees fertilized with NPK 19:19:19 (1.66 and 1.69\%) during the first and second seasons respectively.
With respect to the effect of types of slow-release compound fertilizers on potassium concentration in leaves, in the first season Table 4 revealed that the application of Nitrophoska fertilizer gave the best values without any significant between doses followed by the application of Matador significant differences between different doses. In the second season, potassium concentration in leaves was not affected significantly by applying two types of fertilizers or doses. On the other hand, the lowest significant value of potassium concentration in leaves recorded with application of NPK 19:19:19 fertilizer in the both seasons.

Magnesium concentration in leaves was significantly affected as result of application with two types of slow-release compound fertilizers and doses during both seasons of the study (Table 4). The maximum value of magnesium concentration in leaves was recorded with application of Nitrofoska at $100 \mathrm{~kg} / \mathrm{Fed}$ dan $(0.51$ and $0.76 \%)$ during 2018 and 2019 seasons respectively. Meanwhile, the minimum value of magnesium concentration in leaves was recorded with application of Matador $30 \mathrm{~kg} /$ Feddan (0.19 and 0.25\%) during 2018 and 2019 seasons respectively.

Table 4 Effect of different slow-release compound fertilizer types and doses on some leaf macro elements content of Nonpareil almond young trees

\begin{tabular}{|c|c|c|c|c|c|c|c|c|}
\hline \multirow[t]{2}{*}{ Treatments } & \multicolumn{2}{|c|}{$\begin{array}{l}\text { Nitrogen } \\
\text { (\%) }\end{array}$} & \multicolumn{2}{|c|}{$\begin{array}{l}\text { Phosphorus } \\
\text { (\%) }\end{array}$} & \multicolumn{2}{|c|}{$\begin{array}{l}\text { Potassium } \\
(\%)\end{array}$} & \multicolumn{2}{|c|}{$\begin{array}{l}\text { Magnesium } \\
(\%)\end{array}$} \\
\hline & 2018 & 2019 & 2018 & 2019 & 2018 & 2019 & 2018 & 2019 \\
\hline Matador@ at $30 \mathrm{~kg} /$ Feddan & $1.34 f$ & $1.44 f$ & $1.76 b$ & $1.82 \mathrm{C}$ & $1.77 d$ & $2.11 \mathrm{a}$ & $0.19 \mathrm{~g}$ & $0.25 f$ \\
\hline Matador@ at $60 \mathrm{~kg} /$ Feddan & $1.49 \mathrm{e}$ & $1.45 e$ & $1.82 \mathrm{a}$ & $1.88 \mathrm{~b}$ & $1.82 \mathrm{C}$ & $2.12 \mathrm{a}$ & $0.30 \mathrm{e}$ & $0.33 \mathrm{e}$ \\
\hline Matador@ at $120 \mathrm{~kg} /$ Feddan & $1.50 \mathrm{~d}$ & $1.51 \mathrm{~d}$ & $1.85 \mathrm{a}$ & $1.90 \mathrm{a}$ & $1.89 \mathrm{~b}$ & $2.12 \mathrm{a}$ & $0.37 d$ & $0.42 d$ \\
\hline Nitrophoska@ at 25 kg/Feddan & $1.55 c$ & $1.60 c$ & $1.67 d$ & $1.75 \mathrm{e}$ & $1.99 a$ & $2.13 a$ & $0.43 c$ & $0.55 c$ \\
\hline Nitrophoska@ at $50 \mathrm{~kg} /$ Feddan & $1.66 b$ & $1.69 b$ & $1.70 \mathrm{c}$ & $1.75 \mathrm{e}$ & $2.00 \mathrm{a}$ & $2.15 \mathrm{a}$ & $0.45 b$ & $0.63 b$ \\
\hline Nitrophoska@ at $100 \mathrm{~kg} /$ Feddan & $1.71 \mathrm{a}$ & $1.75 a$ & $1.70 c$ & $1.80 \mathrm{~d}$ & $2.05 a$ & $2.16 a$ & $0.51 a$ & $0.76 a$ \\
\hline Control & $1.22 \mathrm{~g}$ & $1.41 \mathrm{~g}$ & $1.66 d$ & $1.69 f$ & $1.54 \mathrm{e}$ & $1.60 \mathrm{~b}$ & $0.28 f$ & $0.33 \mathrm{e}$ \\
\hline
\end{tabular}

Means in each column with similar letters are not significantly different 
Table 5 Effect of different slow-release compound fertilizer types and doses on some leaf micro elements content of Nonpareil almond young trees

\begin{tabular}{|c|c|c|c|c|c|c|c|c|}
\hline \multirow[t]{2}{*}{ Treatments } & \multicolumn{2}{|l|}{$\begin{array}{l}\text { Zinc } \\
\text { ppm }\end{array}$} & \multicolumn{2}{|l|}{$\begin{array}{l}\text { Iron } \\
\text { ppm }\end{array}$} & \multicolumn{2}{|c|}{$\begin{array}{l}\text { Manganese } \\
\text { ppm }\end{array}$} & \multicolumn{2}{|l|}{$\begin{array}{l}\text { Copper } \\
\text { ppm }\end{array}$} \\
\hline & 2018 & 2019 & 2018 & 2019 & 2018 & 2019 & 2018 & 2019 \\
\hline Matador@ at $30 \mathrm{~kg} /$ Feddan & $21.33 f$ & $43.98 b$ & $106.1 f$ & $110.1 \mathrm{~g}$ & $24.36 \mathrm{~g}$ & $35.49 \mathrm{e}$ & $25.16 c$ & $30.27 \mathrm{~b}$ \\
\hline Matador@ at $60 \mathrm{~kg} /$ Feddan & $36.69 b$ & $44.06 b$ & $112.4 d$ & 118.0e & $34.80 d$ & $40.09 d$ & $25.16 c$ & $37.54 b$ \\
\hline Matador@ at $120 \mathrm{~kg} /$ Feddan & $37.00 \mathrm{a}$ & $45.00 \mathrm{a}$ & $114.1 \mathrm{c}$ & $119.3 d$ & $52.20 \mathrm{a}$ & $55.37 a$ & $37.70 a$ & $40.11 a$ \\
\hline Nitrophoska@ at 25 kg/Feddan & $25.66 d$ & $35.98 d$ & $114.1 \mathrm{c}$ & $120.4 c$ & $36.54 c$ & $41.12 \mathrm{c}$ & $36.14 b$ & $38.00 \mathrm{~b}$ \\
\hline Nitrophoska@ at 50 kg/Feddan & $32.29 c$ & $40.27 c$ & $117.4 b$ & $120.9 b$ & $31.32 \mathrm{e}$ & $40.00 d$ & $25.16 c$ & $30.48 c$ \\
\hline Nitrophoska@ at $100 \mathrm{~kg} /$ Feddan & $37.08 \mathrm{a}$ & $45.20 \mathrm{a}$ & $168.8 \mathrm{a}$ & $170.1 \mathrm{a}$ & $41.76 b$ & $49.03 b$ & $37.74 a$ & $40.00 \mathrm{a}$ \\
\hline Control & $22.74 \mathrm{e}$ & $40.11 c$ & 111.7e & $115.2 f$ & $29.59 f$ & $39.84 d$ & $25.16 c$ & $27.05 d$ \\
\hline
\end{tabular}

Means in each column with similar letters are not significantly different

Results in Table 5 indicated that application with Nitrophoska at $100 \mathrm{~kg} /$ Feddan and Matador at $120 \mathrm{~kg} /$ Feddan recorded the highest value of zinc concentration in leaves without significant differences between them ( 37.08 and 45 , and 37 and $45.20 \mathrm{ppm}$ ) in both of seasons respectively. The lowest value of zinc concentration in leaves was recorded by application of Matador at $30 \mathrm{~kg} /$ Feddan and fast-release fertilizer NPK 19:19:19 (21.33 and $40.11 \mathrm{ppm}$ ) in the first and second seasons respectively.

Also, results in Table 5 obviously showed that the highest significant value of iron concentration in leaves was recorded by application of Nitrophoska at100 kg/ Feddan (168.8 and $170.1 \mathrm{ppm}$ ) during 2018 and 2019 seasons respectively. Meanwhile, the lowest significant value of iron concentration in leaves was recorded with application of Matador $30 \mathrm{~kg} /$ Feddan (106.1 and 110.1 ppm) during 2018 and 2019 seasons respectively.

The application of Matador $120 \mathrm{~kg} /$ Feddan was recorded the highest significant value of manganese concentration in leaves (52.20 and $55.37 \mathrm{ppm}$ ) during 2018 and 2019 seasons respectively, while the application of Matador $30 \mathrm{~kg} /$ Feddan recorded the lowest significant value of manganese concentration in leaves (24.36 and $35.49 \mathrm{ppm}$ ) during 2018 and 2019 seasons during both seasons respectively (Table 5).

As for copper concentration in leaves, results in the first season showed that the application with Nitrophoska at $100 \mathrm{~kg} /$ Feddan recorded the highest value followed by Matador at $120 \mathrm{~kg} /$ Feddan (37.74 and 37.70 ppm) respectively without significant differences between them. On the contrary, there was no significant differences between application with Matador at 30 and $60 \mathrm{~kg} /$ Feddan and Nitrophoska at $50 \mathrm{~kg} /$ Feddan compared with fast-release fertilizer NPK 19:19:19. In the second season, Matador at $120 \mathrm{~kg} /$ Feddan gave the highest value followed by Nitrophoska at $100 \mathrm{~kg} /$ Feddan (40.11 and $40 \mathrm{ppm})$ respectively without significant differences between them while application with fast- release fertilizer NPK 19:19:19 gave the lowest significant value of copper concentration in leaves $(27.05 \mathrm{ppm})$ (Table 5).

\section{Discussions}

The enhancement in vegetative growth characteristics and leaf mineral contents of Nonpareil almond young trees may be attributed to the use of slow-release compound fertilizers, Matador and Nitrophoska, of which content of many nutrients (nitrogen, phosphorus, potassium, calcium, magnesium, iron, copper, sulfur, and manganese) and their effects on regulating the release of these nutrients according to the necessity of trees. Matador and Nitrophoska contain nitrogen (20 and 25\%, respectively) higher than the fast-release fertilizer NPK 19: $19: 19$, as it is known that the role of nitrogen in plants especially in the vegetative growth stage of trees increases growth and development of all living tissue by elongation of internodes; also, nitrogen is considered an important constituent of chlorophyll, protoplasm, protein, and nucleic acid, so that it resulted in an increase in number and size of cells. Potassium is an essential macro-element required in large amounts for normal plant growth and development (Amal et al., 2017). Potassium increases the photosynthetic rates of leaves, $\mathrm{CO}_{2}$ assimilation and facilitates carbon movement (Nabila et al., 2015). According to Bolland et al. (1991), early plant growth is particularly dependent on phosphorus because it needs rapid cell division and adequate nitrogen supply that produces wall leaf and stem development. In addition, the substantial improvement of vegetative growth due to sulfur may be attributed to acidification resulted from sulfur oxidation that decrease soil $\mathrm{pH}$ which enhances the solubility of nutrients and increases the activity of micro-organisms. These effects increase the nutrients availability uptake and translocation and increase the vegetative growth of trees. Also, it may explain the superiority of Nitrophoska than Matador especially Nitrophoska at $100 \mathrm{~kg} /$ Feddan in 
improving the most growth measurements and leaf nutritional status of Nonpareil almond young trees, in particularly the high content of the first than the second from $\mathrm{N} 25 \%$, K $17.15 \%, \mathrm{~S} 4 \%, \mathrm{Mg} 1.55 \%$, B $0.01 \%$, Cu $0.019 \%$, Fe $0.05 \%$, Mn $0.05 \%$, Mo $0.001 \%$, and $\mathrm{Zn}$ $0.019 \%$ which provide trees with its requirement of elements all over the growing season and help absorption of nutrients from the soil as indicated by high macro and micro elements percentages in leaves compared with fast-release mineral fertilizer NPK 19:19:19 (Tables 4 and 5).

Our results seem to support the recent view that slowrelease fertilizer substances are only slightly soluble and require additional time for mineralization, thereby giving them slow-release properties. According to Borges et al. (2015), slow-release fertilizer materials may be organic or inorganic; a primary example of an organic slowrelease fertilizers is compost while inorganic examples include urea-based fertilizers (such as urea formaldehyde, isobutylidenediurea, and triazone), magnesium ammonium phosphates and other materials which degrade biologically and are not easily soluble (Tong et al., 2009; Qiwu, 2009). In addition to the efficiency of fertilizers dissolution is very important in the plants' adsorption of fertilizers; the current technology to produce slow-release fertilizers is mainly polymer film coating of a fertilizer grain (Liang and Liu, 2006; Wu and Liu, 2008; Calabria et al., 2012); this coating changes the nutrient solubility characteristics and lengthens and controls nutrient release consequently improving fertilizer use efficiency and minimizing pollution to the environment due to fertilizers losses (AlShamaileh et al., 2018). In contrast, the traditional chemical fertilizers often cause resource waste because the release rate per unit time of nutrients is usually much higher than the adsorption rate by plants, leading to environmental pollution and other problems. Moreover, the long-term use of these fertilizers may cause soil compaction and decrease of yield (Azeem et al., 2014).

The results indicated that Matador and Nitrophoska have good slow-release compound fertilizers which provided an efficient way of supplying trees with essential elements to growth especially under sandy soil conditions such as Nubaria region which is characterized with poor fertility, low water holding capacity, and easily leaching of nutrients from the soil as well as to prevent environmental pollution compared with fast-release mineral fertilizer and cost-saving, thus can efficiently improve the utilization efficiency of fertilizers. These results are in accordance with those obtained by Wen et al. (2016); slow-release fertilizers may be a promising approach to alleviate such problems and improve nutrient utilization efficiency at the same time directly through its design at form releases the nutrients gradually at the rate in accordance with the nutrient requirement of the plants, which is conducive to the reduction of nutrient loss (Teodorescu et al., 2009). Also they gave the highest values of residual elements in soil due to their low activity index, compared with the fastrelease mineral fertilizer which gave the lowest values of available elements left in the soil (Mikkelesen et al., 1994). Moreover, the advantages of using slow-release fertilizers instead of conventional fertilizers are various, such as higher efficiency of the fertilizer, the continuous supply of nutrients for a prolonged period, and lower nutrient losses due to volatilization and leaching (Chawakitchareon et al., 2016 and Pang et al., 2018).

\section{Conclusions}

Through the previous results it could be concluded that the slow nutrient release of slow-release fertilizers can facilitate the continuous supply of nutrients for the plants, thereby preventing leaching losses commonly observed with traditional fertilizers. Our results show the possibility of using slow-release compound fertilizers such as Matador and Nitrophoska especially Nitrophoska at $100 \mathrm{~kg} /$ Feddan to maximize growth and leaf mineral contents of Nonpareil almond young trees grown under Nubaria condition.

\section{Abbreviations \\ SLDW: Specific leaf dry weight; SRF: Slow-release fertilizer}

\section{Acknowledgements \\ Authors would like to express their grateful for National Research Centre (NRC), Egypt for supporting and offering generous funding for the project "Technology of cultivating some promising fruit trees under sandy soil conditions of Nubaria."}

\section{Authors' contributions}

AMS and NEK designed this work. ERA and OAA designed and conducted the field experiment treatments and following up the growth of almond trees. TSMM and AMR performed the chemical analysis of the samples, coordinated the data collection for analysis. TSMM performed data statistical analysis and also wrote the manuscript. ARMS reviewed the manuscript. All authors read and approved the final version.

\section{Authors' information}

Dr. Nabila El Badawy Kaseem is a professor at Department of Horticultural Crops Technology, Agricultural and Biological Division, National Research

Center, Dokki, Giza, Egypt.

Dr. Mahmoud Sami Abourayya is a professor at Department of Horticultural Crops Technology, Agricultural and Biological Division, National Research Center, Dokki, Giza, Egypt.

Dr. Thanaa Shaban Mohamed Mahmoud is an associate professor at Department of Horticultural Crops Technology, Agricultural and Biological Division, National Research Center, Dokki, Giza, Egypt.

Dr. Ramadan Ahmed Eisa is an associate professor at Department of Horticultural Crops Technology, Agricultural and Biological Division, National Research Center, Dokki, Giza, Egypt.

Dr. Amal Masood Rakha is a researcher at Department of Horticultural Crops Technology, Agricultural and Biological Division, National Research Center, Dokki, Giza, Egypt.

Dr. Osama Abdelfattah Amin is an associate professor at Department of Horticultural Crops Technology, Agricultural and Biological Division, National Research Center, Dokki, Giza, Egypt. 


\section{Funding}

This work was supported and funded by National Research Centre through the project titled: Technology of cultivating some promising fruit trees under sandy soil conditions of Nubaria. Project ID: 11030146, during 2016/2019.

\section{Availability of data and materials}

The datasets generated and/or analyzed during the current study are included in this published.

\section{Ethics approval and consent to participate}

Not applicable

\section{Consent for publication}

Not applicable

\section{Competing interests}

The authors declare that they have no competing interests.

Received: 3 October 2019 Accepted: 3 December 2019

Published online: 12 December 2019

\section{References}

AlShamaileh E, Al-Rawajfeh AE, Alrbaihat M (2018) Mechanochemical synthesis of slow-release fertilizers: a review. The Open Agriculture Journal 12:11-19

Amal GA, Nabila MZ, Hassanein MS, Manal FM (2017) Effect of the complete foliar fertilizer nitrophoska foliar 20/19/19/TE on growth, yield, yield components and some chemical composition of two barley cultivars under newly reclaimed sandy soil. Middle East J. Agric. Res. 6(4):1038-1044

AOAC (1985) Official methods of analysis. Association of Official Agricultural Chemists, $14^{\text {th }}$ ed: Benjamin Farnklin station Washington, DC, USA: 490-510

Azeem B, Kushaari K, Man ZB, Basit A, Thanh TH (2014) Review on materials \& methods to produce controlled release coated urea fertilizer. Journal of Controlled Release 181:11-21

Bolland MDA, Bowden JW, Brennan RF, Cartroll JW, Mason MG, Porter WP (1991) Wheat nutrition. In: The wheat book: a technical manual for wheat producers compiled by Michael Perry and Brain Hillman; pp 55-76.

Borges R, Brunatto SF, Leitao AA, Decarvalho GSG (2015) Wypych F (2015) Solidstate mechanochemical activation of clay minerals and soluble phosphates mixtures to obtain slow-release fertilizers. Clay Miner 50:153-162. https://doi. org/10.1180/claymin.2015.050.2.01

Calabria L, Vieceli N, Bianchi O, Rv BDO, Do NFI, Schmidt V (2012) Soy protein isolate/poly(lactic acid) injection-molded biodegradable blends for slow release of fertilizers. Industrial Crops and Products 36(1):41-46

Chawakitchareon P, Anuwattana R, Buates J (2016) Advanced materials: manufacturing, physics, mechanics and applications. Springer, Azov, Russia, pp 129-137

Himmah NIF, Djajakirana G, Darmawan D (2018) Nutrient release performance of starch coated NPK fertilizers and their effects on Corn growth. Sains Tanah J Soil Sci Agroclimatol 15(2):104-17

Liang R, Liu M (2006) Preparation and properties of coated nitrogen fertilizer with slow release and water retention. Ind Eng Chem Res 45:8610-8616

Mikkelesen RL, Williams HM, Behel AD (1994) Nitrogen leaching and plant uptake from controlled release fertilizaers. Fert. Res. 37:43-50

Mstat-C (1989) Users guide: a micro-computer program for the design, management and analysis of agronomic research experiments. Michigan University, East Lansing, Mc, USA

Nabila MZ, Amal GA, Hassanein MS, Mirvat EG (2015) Response of two wheat cultivars to foliar fertilizer in newly cultivated land. Middle East J. Agric. Res. 4(2):283-290

Pang WD, Hou H, Wang S, Sai B, Wang J, Ke G, Wu QL, Holtzapplec MT (2018) Preparation of microcapsules of slow-release NPK compound fertilizer and the release characteristics. J Braz Chem Soc 29(11):2397-2404

Qiwu Z (2009) Mechanochemical synthesis of slow-release fertilizers through incorporation of alumina composition into potassium/ammonium phosphates. J Am Ceram Soc 92(12):3070-3073. https://doi.org/10.1111/j. 1551-2916.2009.03291.x

Shaviv A, Mikkelsen RL (1993) Controlled-release fertilizers to increase efficiency of nutrient use and minimize environmental degradation - a review. Fertilizer Research 35(1):1-12

Teodorescu M, Lungu A, Stanescu PO, Neamtu C (2009) Preparation and properties of novel slow-release NPK Agrochemical formulations based on poly(acrylic acid) hydrogels and liquid fertilizers. Ind Eng Chem Res 48(14): 6527-6534

Tong Z, Yuhai L, Shihuo Y, Zhongvib H (2009) Superabsorbent hydrogels as carriers for the controlled release of urea: experiments and a mathematical model describing the release rate. Biosystems Engineering 102:44-50

Wen P, Wu Z, He Y, Ye B, Han Y, Wang J, Guan X (2016) Microwave-assisted synthesis of a semi-interpenetrating polymer network slow-release nitrogen fertilizer with water absorbency from cotton stalks. ACS Sustainable Chem Eng 4:6572-6579

Wu L, Liu M (2008) Preparation and properties of chitosan-coated NPK compound fertilizer with controlled-release and water-retention. Carbohydrate Polymers 72(2):240-247 https://doi.org/10.1016/J.CARBPOL. 2007.08.020

\section{Publisher's Note}

Springer Nature remains neutral with regard to jurisdictional claims in published maps and institutional affiliations.

\section{Submit your manuscript to a SpringerOpen ${ }^{\circ}$ journal and benefit from:}

- Convenient online submission

- Rigorous peer review

- Open access: articles freely available online

- High visibility within the field

- Retaining the copyright to your article

Submit your next manuscript at $\boldsymbol{\nabla}$ springeropen.com 